\section{Regarding micro-RNA-181a-5p antisense oligonucleotides attenuate osteoarthritis in facet and knee joints}

I read with considerable interest the paper by Nakamura and colleagues dealing with the potential therapeutic use of a locked nucleic acid, antisense oligonucleotide (LNA ASO) against a micro-RNA in osteoarthritis (OA). ${ }^{1}$ I was particularly impressed with the Osteoarthritis Research Society International and cellularity scores as well as the data on degenerative markers and chondrocyte apoptosis/death from the in vivo animal models. Nonetheless, I had a couple of questions that I hope the authors can help me with.

First, was the reason you had to employ TransFectin Lipid Reagent to transfect the in vitro grade LNA ASO because it was $21 \mathrm{bp}$, as opposed to the shorter, $16 \mathrm{bp}$ in vivo grade LNA ASO for which you apparently did not employ lipofection to transfect chondrocytes? $?^{2}$

Second, for the human fluorescense activated cell sorter (FACS) data looking at chondrocyte apoptosis/cell death, why employ 'gaps' (figure $6 \mathrm{E}$ ) rather than a head-to-head comparison of interleukin-1 $\beta$ (IL-1 $\beta$ )-treated cultures to demonstrate a statistically lower number of apoptotic/dead chondrocytes in the LNA ASO-treated cultures, when you were able to demonstrate a statistical difference in head-to-head comparisons in both animal models (supplemental figs. $2 \mathrm{~F}, \mathrm{H}$ )?

In looking at the raw data in supplementary figure 13 and performing an unpaired, two-tailed, t-test, I found that a headto-head comparison of the LNA ASO and control-treated chondrocytes exposed to IL-1 $\beta$ was not statistically different in the number of apoptotic/dead chondrocytes $(p=0.0901)$. Was this the reason that the authors chose to look at gaps rather than a head-to-head comparison?

If that was the case, one might ask how was a significant difference in 'gaps' possible? I would posit that it was due to a 'floor effect' produced by significantly higher numbers of apoptotic/ dead chondrocytes in the LNA ASO-treated, IL-1 $\beta$, un-exposed cultures. Indeed, when one performs an unpaired, two-tailed, $\mathrm{t}$-test on the raw data in supplementary figure 13, there was a significantly greater number of apoptotic/dead chondrocytes in the LNA ASO-treated compared with the control-treated groups that were not exposed to IL-1 $\beta$ ( $p=0.0108)$.

That brings up the uncomfortable question: why would LNA ASO in phosphate-buffered saline (PBS) produce more dead human knee chondrocytes than control oligo in PBS? And, perhaps more concerning is the question, what does that imply about the clinical efficacy and safety of such an agent in human $\mathrm{OA}$ ?

Although I suspect, ultimately, only clinical trials would be able to answer some of these queries, I would appreciate knowing the authors thoughts on all of them.

\section{Michael R Liebling (ㅇ}

Department of Medicine, Division of Arthritis and Rheumatic Disease, Oregon Health and Science University, Portland, OR 97239, USA

Correspondence to Dr Michael R Liebling, Division of Arthritis and Rheumatic Disease, Oregon Health and Science University, Pleasant Hill, OR 97455, USA; mrliebling@gmail.com

Contributors MRL is the sole contributor to this correspondence.

Funding The authors have not declared a specific grant for this research from any funding agency in the public, commercial or not-for-profit sectors.

Competing interests None declared.

Patient consent for publication Not required.

Provenance and peer review Not commissioned; internally peer reviewed.

(c) Author(s) (or their employer(s)) 2020. No commercial re-use. See rights and permissions. Published by BMJ.

\section{Check for updates}

To cite Liebling MR. Ann Rheum Dis 2020;79:e69.

Received 28 March 2019

Accepted 2 April 2019

Published Online First 2 May 2019

\section{SLinked}

http://dx.doi.org/10.1136/annrheumdis-2019-215509

Ann Rheum Dis 2020;79:e69. doi:10.1136/annrheumdis-2019-215454

ORCID iD

Michael R Liebling http://orcid.org/0000-0002-3319-0950

\section{REFERENCES}

1 Nakamura A, Rampersaud YR, Nakamura S, et al. microRNA-181a-5p antisense oligonucleotides attenuate osteoarthritis in facet and knee joints. Ann Rheum Dis 2019;78:111-21.

2 Straarup EM, Fisker N, Hedtiärn M, et al. Short locked nucleic acid antisense oligonucleotides potently reduce apolipoprotein $B$ mRNA and serum cholesterol in mice and non-human primates. Nucleic Acids Res 2010;38:7100-11. 